Zoologica Poloniae (2011) 56/1-4: 11-17

DOI: $10.2478 / \mathrm{v} 10049-011-0004-8$

\title{
HOW PRECISE ARE SIZE-BASED AGE ESTIMATIONS IN THE SAND LIZARD (LACERTA AGILIS)?
}

\author{
BARTOSZ BORCZYK and ŁUKASZ PAŚKO
}

Laboratory of Vertebrate Biology and Conservation, Institute of Zoology, University of Wrocław, Sienkiewicza Street 21, PL-50-335 Wrocław, Poland

${ }^{1}$ e-mail: borczyk@biol.uni.wroc.pl

\begin{abstract}
Reptiles show a positive correlation between age and body size and it is common practice to infer the age of an animal from its size. However, the growth rate often differs between individuals, thus such practice may lead to false conclusions. Because age of an animal is a very important factor in many ecological studies, it should be determined with a minimum of error. Here, we compare the body size distribution among different age classes of the sand lizard (Lacerta agilis) to infer if it is possible to correctly determine their age on the basis of the body length. Our results show that the average error in age estimation on the basis of the lizard size is 1.36 year which is approximately $1 / 3$ the average sand lizard life span.
\end{abstract}

Key Words: Reptilia, Squamata, Lacertidae, Lacerta agilis, age, skeletochronology, growth rate

\section{INTRODUCTION}

Age determination is very important in ecological studies. Reptiles show a positive correlation between age and body size, which is often used to estimate the age of an animal from its size (e.g., Szafrańska 1978, Gvozdik 2000, CAstoe 2002). However, it was shown that only two methods guarantee actual age determination in terrestrial vertebrates: mark-recapture and skeletochronology (HAlliday and Verrell 1988); estimation of age on the basis of animal size may contain significant error. This is because growth rates may differ between populations, specimens from a single population, and between sexes. Thus one can 
easily reach a false conclusion that, for example, a habitat is preferred by young specimens because only small lizards are found in it, while in fact both young and old animals are present. Similarly, reactions to predator attack or reproductive success may depend on age or size (e.g. Olsson and Shine 1996).

In order to minimize the potential for error, researchers usually subdivide population into two, three or, rarely, four age classes. For example, CASTOE (2002), subdivided a population of rainforest hognosed vipers (Porthidium nasutum) into adults and subadults, and Gvozdik (2000) assigned the sand lizards (Lacerta agilis) into three classes, hatchlings, overwinterings, and individuals two or more years old. However, even the hatchlings vary considerably in their snout-vent length (SVL) within single sand lizard populations as demonstrated by the ranges of 35-55 mm (Angel 1947), 30-35 mm (Y АвLOKоv 1976), and 26-31 mm (BArus and Oliva 1992). This variation increases after several months of intensive feeding and growth.

Although some authors cautioned that aging animals based on their body size involves a risk of substantial error (e.g. SMIRINA 1974), there has been no serious research dedicated to this subject. Therefore, it seems important to assess the error of size-dependent age estimation.

\section{MATERIAL AND METHODS}

Sand lizard specimens of both sexes $(\mathrm{N}=187,52$ males, 122 females, and 13 unsexed) from eight lowland and highland populations within Poland were used in a broader study (BORCZYK et al., 2004, BORCZYK in preparation). Lizards were captured by hand and released shortly after measurements and toe clipping (the third toe from left hind foot was removed). The SVL was measured with calipers and rounded to the nearest millimeter. Because lizards (especially young individuals) grow rapidly, it was important to collect all measurements in the shortest time interval to compare size of the individuals of the same age. Thus, all lizards were captured in a two week period at the end of July and beginning of August 2000. We choose this time of the year to minimize possible disturbance of the population because it is after the mating season (end of April, May, and early June, depending on the weather and geographical conditions), and after egg laying (which is usually over at the end of June - end of July).

The age of the lizards was estimated by skeletochronology. The accuracy of this method was confirmed for the sand lizards by SMirina (1974). We followed a modified protocol of SMirina (1974) and Castanet and SMirina (1990). We used the third phalange from the third toe of the left hind foot. The cleared, decalcified, and dehydrated bones were embedded in the paraffin and sectioned at $15 \mu \mathrm{m}$ using a RM 2155 Leica microtome. Sections were stained with MAYER haematoxylin and mounted in DPX. Age was determined by counting the lines of the arrested growth (LAG), which are visible on the bone cross section as dark rings. In Lacerta agilis LAG's are formed annually (SMIRINA 1974), as in the majority of temperate amphibians and reptiles. In older specimens, the most 
inner part of periosteal bone sometimes may be replaced by endosteal bone and expanding marrow cavity leading to partly or complete resorption of the first LAG. To avoid missing the first winter LAG, we referred to the cross sections of the phalanges of laboratory reared sand lizards at the age of their first hibernation. If the marrow cavity was significantly greater than their phalange diameter we assumed resorption of the first LAG (for more details see CASTANET and Smirina 1990). The complete resorption of the first LAG was observed in $23.5 \%$ of all examined specimens.

In order to assess the reliability of size-based age estimations, a linear regression of the age (y) on log transformed SVL (x) was performed, the values of $\mathrm{p}, \mathrm{r}$, and $\mathrm{r}^{2}$ were calculated, and the prediction interval of age for body length determined (Figure 1). A standard deviation for the age expected from linear regression was also calculated, showing an average age estimation error (in years) for random drawn specimens of known size (GondKA et al. 1994). Because of the small sample size per population, we ran an analysis for all lizards plus separately for males and females to avoid error resulting from possible sexual dimorphism in growth rate. There might also be some differences between populations in growth rate, however, researchers rarely conduct rigorous studies on growth rate patterns in studied populations and usually assume that the given size range refers to a given age class, thus ignoring possible inter-population differences do not affect our results.

\section{RESULTS}

Age and SVL are highly correlated in the studied species $\left(\mathrm{p}<0.0001, \mathrm{r}=0.82 \mathrm{r}^{2}\right.$ $=0.67$ ), however the standard error was as high as 1.36 years (Fig. 1a), showing that age estimations of sand lizards based on their size may indeed contain significant errors. When sexes were analyzed separately, the standard error was 1.17 years for females $\left(\mathrm{p}<0.0001, \mathrm{r}=0.87, \mathrm{r}^{2}=0.76\right)$ (Fig. 1b) and 1.2 years for males $\left(p<0.0001, r=0.85, r^{2}=0.73\right)$ (Fig. 1c). After the first winter, as a result of intraspecific growth rate variation, the size ranges of yearlings and two-year old lizards overlapped, although the average length of yearlings was smaller than the minimal length of two year olds. After the second winter, it was impossible to assign lizards to any age class (Fig. 1, Table 1).

\section{DISCUSSION}

The average error of 1.36 years equals approximately $1 / 3$ the average sand lizard life span (Вовсzук et al. 2004). When sexes are analyzed separately, the errors of age estimation are lower, but nevertheless high: 1.2 and 1.17 year for males and females respectively. This obviously results from differences in growth rate between males and females (e.g. Guarino et al. 2010), being adaptations for different reproductive roles. 


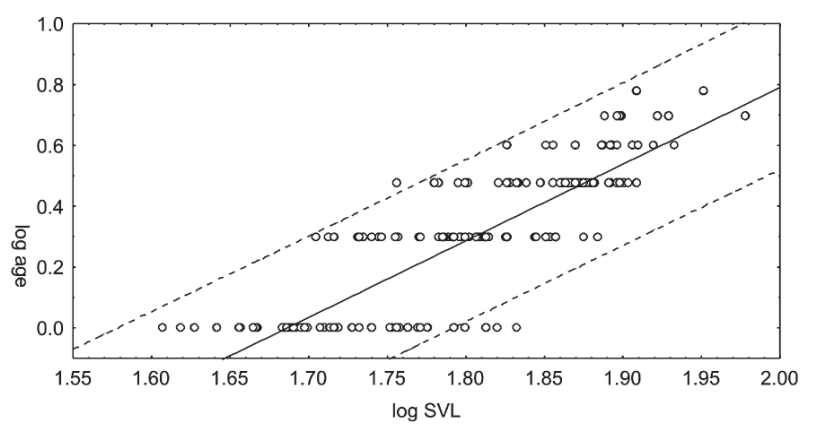

a
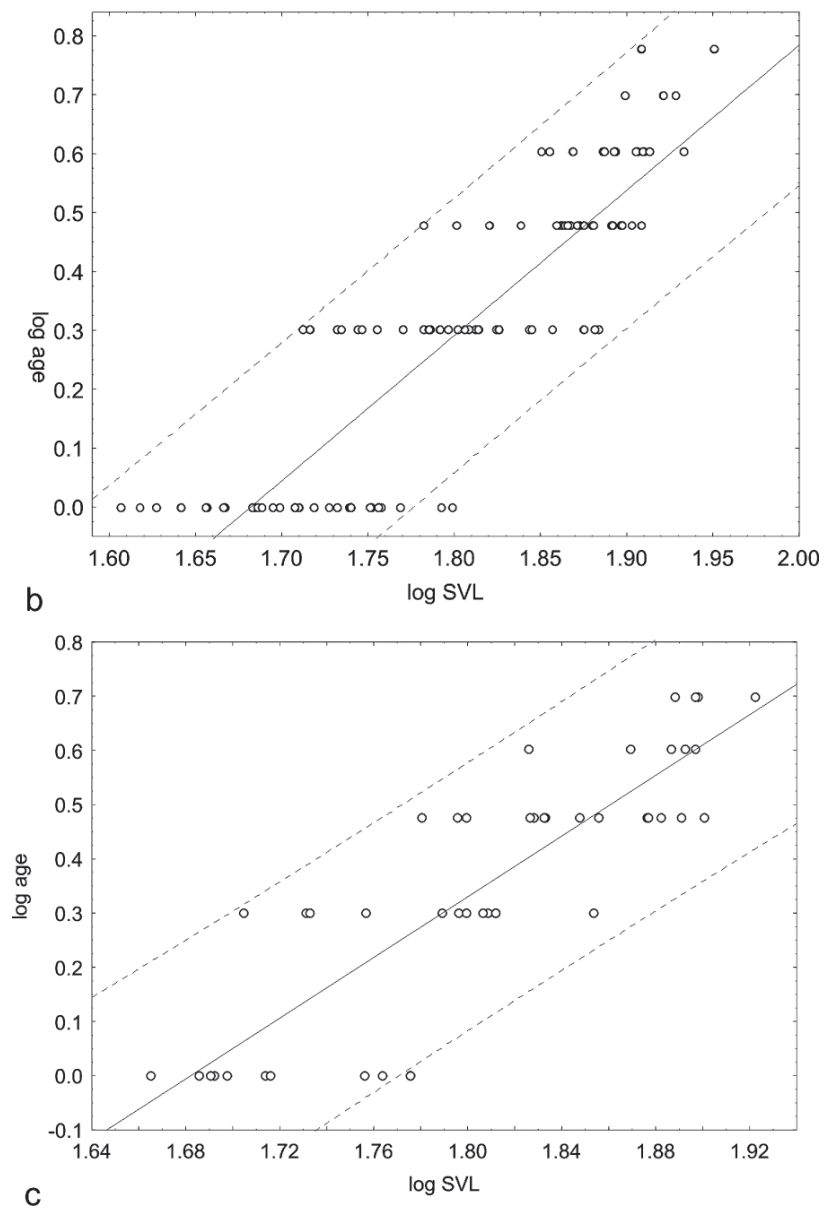

Figure 1. Linear regression for log age on log snout-vent length for sand lizard (Lacerta agilis). Prediction interval marked by interrupted lines. a) regression for both males, females and juveniles $\left(\log\right.$ age $\left.=-4.25+2.25 \log \mathrm{SVL} ; \mathrm{p}<0.0001, \mathrm{r}=0.82, \mathrm{r}^{2}=0.67\right)$, b) regression for females, $\left(\log\right.$ age $=-4.15+2.5 \log \mathrm{SVL}$; $\left.\mathrm{p}<0.0001, \mathrm{r}=0.87, \mathrm{r}^{2}=0.76\right)$, c) regression for males $\left(\log\right.$ age $\left.=-4.7+2.8 \log \mathrm{SVL} ; \mathrm{p}<0.0001, \mathrm{r}=0.85, \mathrm{r}^{2}=0.73\right)$. 
Table 1. Size range, means and standard deviations at given age in the sand lizard (Lacerta agilis).

\begin{tabular}{ccccc}
\hline age & \multicolumn{2}{c}{ Males } & \multicolumn{2}{c}{ Females } \\
\cline { 2 - 5 } & min-max & $\mathrm{x} \pm \mathrm{SD}$ & $\min -\max$ & $\mathrm{x} \pm \mathrm{SD}$ \\
\hline 1 & $46.2-59.6$ & $62.78 \pm 4.87$ & $40.4-63.0$ & $51.75 \pm 5.75$ \\
2 & $50.7-71.4$ & $60.99 \pm 5.92$ & $51.6-76.5$ & $63.45 \pm 6.82$ \\
3 & $60.3-79.5$ & $70.15 \pm 6.03$ & $60.6-80.0$ & $74.12 \pm 50.4$ \\
4 & $66.9-78.8$ & $74.95 \pm 4.83$ & $70.9-85.7$ & $78.31 \pm 4.23$ \\
5 & $77.3-83.6$ & $79.68 \pm 2.72$ & $79.2-84.9$ & $82.53 \pm 2.97$ \\
6 & & & $81.0-89.3$ & $85.15 \pm 5.87$ \\
\hline
\end{tabular}

There is high individual variation in growth rate, in some cases being twofold. However, even hatchlings differ considerably in their SVL, as reported by different authors ranging from only $26 \mathrm{~mm}$ (BARUS and OLIVA 1992) to $55 \mathrm{~mm}$ (ANGel 1947). These differences may become even more visible after a period of intensive feeding and growth (see Fig. 1).

Individuals from different populations or different sexes might differ in growth rate (e.g. WAPSTRA et al. 2001). One could say this might influence our results due to including specimens from eight separate populations in our sample. However, during field studies, researchers rarely do experiments designed for estimation of accurate growth rate of lizards from a given population. It is commonly assumed that one can estimate approximate lizard age based on external characteristics without long-term mark-recapture or skeletochronology based research (e.g. GvozDik 2000). Combining the results from multiple populations we demonstrate, that such approach bear significant errors. Thus any attempts to infer the age of an animal based on its size should be done with caution and taken as a rough approximation. The problem may be even more complicated, because lizards as ectotherms strongly depend on external conditions (e.g. temperature, length of activity period, etc.), between-seasonal differences in growth pattern likely exist (e.g. Roitberg and SMirina 2006a,b). Although our data are restricted only to the sand lizard, it is probable that similar patterns might be observed in other squamate species as well.

\section{Acknowledgments}

The study was carried out with a Ministry of the Environment permit (DLOPiK og-4201-78/00). 


\section{JAK PRECYZYJNE JEST OKREŚLANIE WIEKU NA PODSTAWIE DŁUGOŚCI CIAŁA U JASZCZURKI ZWINKI (LACERTA AGILIS)?}

Ponieważ gady wykazują pozytywną korelację między wiekiem a rozmiarami ciała wnioskowanie o wieku zwierzęcia na podstawie jego rozmiarów jest stosunkowo częstą praktyką. Niestety, tempo wzrostu często różni się między poszczególnymi osobnikami i w konsekwencji taka praktyka może prowadzić do błędnych wniosków. Ponieważ wiek zwierzęcia jest istotnym czynnikiem w wielu ekologicznych badaniach, powinien być określany bez większych błędów. W niniejszej pracy podejmujemy próbę oszacowania błędu popełnianego przy próbie wnioskowania o wieku jaszczurek w oparciu o ich rozmiary. Nasze wyniki wskazują, że przeciętny błąd przy określaniu wieku zwierzęcia na podstawie długości jego ciała wynosi 1.36 roku, co w przybliżeniu jest równe $1 / 3$ średniej długości życia jaszczurki zwinki.

Key Words: Reptilia, Squamata, Lacertidae, Lacerta agilis, wiek, szkieletochronologia, tempo wzrostu

\section{REFERENCES}

Angel F. 1947: Vie et moeurs des amphibiens. Payot. Paris. (in French)

Barus V., Oliva O. 1992: Plazi - Reptilia. Academia, Prague. (in Czech)

Borczyk B., Maślak R., Paśko Ł. 2004: How long live sand lizard (Lacerta agilis). In: Biologia płazów i Gadów - Ochrona Herpetofauny. A Converence Proceedings. (Ed. Zamachowski, W.) Wydawnictwo Naukowe Akademii Pedagogicznej, Kraków: 23-24. (in Polish)

Castanet J., Francillon-Viellot H., Meunier F.J., de Ricqles A. 1993: Bone and individual aging. In: Bone. Vol. 7: Bone growth - B. (Ed. Hall, B.K.): CRC Press, Boca Raton: 245-283.

Castanet J., Smirina E.M. 1990: Introduction to the skeletochronological method in amphibians and reptiles. Ann. Sci. Nat. ser. Zool. 11: 191-196.

Castoe T.A. 2002: Microhabitat selection in Porthidium nasutum (Serpentes: Viperidae) in Costa Rica, with comments on ontogenetic variation. Herpet. Rev. 33: $174-175$.

Gondka R., Zgierski A., Adamska M. 1994: Biostatystyka w zadaniach. Wydawnictwo Uniwersytetu Łódzkiego, Łódź. (in Polish)

Guarino F.M., Di Giŕ I., Sindaco R. 2010: Age and growth of the sand lizards (Lacerta agilis) from a high Alpine population of north-western Italy. Acta Herpet. 5(1): $23-29$.

Gvozdik L. 2000: Seasonal activity, sex ratio, and abundance in a population of Lacerta agilis Linnaeus, 1758 from the Czech Republic. Herpetozoa 13: 165-169.

Halliday T.R., Verrell P.A. 1988: Body size and age in amphibians and reptiles. J. Herpetol. 22: 253-265.

Olsson M., Shine R. 1996: Does reproductive success increase with age or with size in species with indeterminate growth? A case study using sand lizards (Lacerta agilis). Oecologia 105: 175-178.

Roitberg E.S., Smirina E.M. 2006a: Age, body size and growth of Lacerta agilis boemica and L. strigata (Reptilia, Lacertidae): a comparative study of two closely related lizard species based on skeletochronology. Herpet. J. 16(2): 133-148. 
Roitberg E.S., Smirina E.M. 2006b: Adult body length and sexual size dimorphism in Lacerta agilis boemica (Reptilia, Lacertidae): between-year and interlocality variation. /in:/ Mainland and insular lacertid lizards: a mediterranean perspective (Eds. Corti C., Lo Cascio P., Biaggini M.). Firenze University Press, Firenze: $175-187$.

Smirina E.M. 1974: Prospects of age determination by bone layers in Reptilia. Zool. Zh. 53: 111-117. (in Russian)

SZAFRAŃSKA K. 1978: Characteristics of the forest population of sand lizard (Lacerta agilis agilis L.) in vicinity of Gostynin. Fol. Forest. Pol. Ser. A, 23: 107-121.

Wapstra E., Swan R., O'Reilly J.M., 2001: Geographic variation in age and size at maturity in a small Australian viviparous skink. Copeia 2001: 646-655.

Yablokov A.V. 1976: Prytkaya yeshcheritsa. Nauka, Moskva. (in Russian).

Received: 20-06-2011 